Tropical Journal of Pharmaceutical Research June 2019; 18 (6): 1205-1211

ISSN: $1596-5996$ (print); 1596-9827 (electronic)

(C) Pharmacotherapy Group, Faculty of Pharmacy, University of Benin, Benin City, 300001 Nigeria.

\title{
Hepatotoxic and hematotoxic effects of sage oil-loaded ifosfamide nanoemulsion in Ehrlich ascites carcinoma- bearing mice
}

\author{
Sahar M AlMotwaa ${ }^{1,2}$, Mayson H Alkhatib ${ }^{1,3 \star}$, Huda M Alkreathy \\ ${ }^{1}$ Department of Biochemistry, Faculty of Science, ${ }^{2}$ Department of Chemistry, College of Science and Humanities, Shaqra \\ University, Shagra, ${ }^{3}$ Regenerative Medicine Unit, King Fahd Centre for Medical Research, ${ }^{4}$ Department of Pharmacology, \\ Faculty of Medicine, King Abdulaziz University, Jeddah, Saudi Arabia
}

*For correspondence: Email: mhalkhatib@kau.edu.sa; Tel: +966-599240526; Fax: +966-26400376

Sent for review: 2 February 2019

Revised accepted: 20 May 2019

\begin{abstract}
Purpose: To investigate the hepatotoxic and hematotoxic effects of sage oil-loaded ifosfamide (IFO) nanoemulsion (NE) in Ehrlich ascites carcinoma (EAC)-bearing mice.

Methods: Ifosfamide (IFO) was loaded into a NE containing sage oil, and its hepatotoxic and hematotoxic effects were assessed in EAC-bearing mice. Female Swiss albino mice $(n=50)$ weighing $25-30 \mathrm{~g}$ (mean weight $=27.5 \pm 2.50 \mathrm{~g}$ ) were randomly assigned to five groups of ten mice each. With the exception of group 1, the mice were inoculated intraperitoneally (i.p.) with $2.5 \times 10^{6} \mathrm{EAC/mouse}$ for $48 \mathrm{~h}$. Group I served as negative control, C (-); group II served as positive control, C (+); while groups III - $V$ were treated i.p. with $60 \mathrm{mg} / \mathrm{kg}$ IFO in 0.3mL water (free-IFO); $0.3 \mathrm{~mL} N \mathrm{NE}$ (SAGE-NANO), and 60 $\mathrm{mg} / \mathrm{kg}$ IFO in $0.3 \mathrm{~mL}$ SAGE-NANO (SAGE-IFO), respectively. The treatments were administered for three days.

Results: Treatment with $60 \mathrm{mg} / \mathrm{kg}$ bwt IFO (free-IFO) significantly elevated the activities of aspartate aminotransferase $(A S T)$ and alanine aminotransferase $(A L T, p<0.05)$. However, subsequent treatment with SAGE-IFO significantly reduced the activity of these liver enzymes $(p<0.05)$. The concentration of reduced glutathione (GSH) as well as the activities of catalase and glutathione reductase (GR) significantly increased, while malondialdehyde (MDA) level decreased significantly in SAGE-IFO group, when compared with free-IFO group $(p<0.05)$. Treatment with SAGE-IFO significantly restored white blood cell (WBC) count and platelet levels which were altered by free-IFO $(p<0.05)$.

Conclusion: The results obtained in this study suggest that loading IFO in sage oil-NE greatly reduces its hepatotoxicity and hematotoxicity.
\end{abstract}

Keywords: Ehrlich ascites carcinoma, Nanoemulsion, Oxidative stress, Sage oil, Hepatotoxicity, Hematotoxicity

This is an Open Access article that uses a fund-ing model which does not charge readers or their institutions for access and distributed under the terms of the Creative Commons Attribution License (http://creativecommons.org/licenses/by/4.0) and the Budapest Open Access Initiative (http://www.budapestopenaccessinitiative.org/read), which permit unrestricted use, distribution, and reproduction in any medium, provided the original work is properly credited.

Tropical Journal of Pharmaceutical Research is indexed by Science Citation Index (SciSearch), Scopus, International Pharmaceutical Abstract, Chemical Abstracts, Embase, Index Copernicus, EBSCO, African Index Medicus, JournalSeek, Journal Citation Reports/Science Edition, Directory of Open Access Journals (DOAJ), African Journal Online, Bioline International, Open-J-Gate and Pharmacy Abstracts

\section{INTRODUCTION}

Nanoemulsion (NE) consists of an emulsifying agent, water and oil phases. Oil-in-water NEs are colloidal systems in which the oil droplet is dispersed in water and produces micelles with small droplet sizes of 20 to $200 \mathrm{~nm}$, which serve as drug carriers [1]. Essential oils (EOs) exhibit antioxidant, antifungal, antibacterial, antiinflammatory, antitumor, and antiviral activities. 
However, their volatility and hydrophobicity limit their applications in food and pharmaceutical industries. Incorporation of EOs into emulsions increases their dispersibility and solubility in aqueous phases [2]. The anticancer activity of various EOs when incorporated into NEs in vitro have been reported $[3,4]$. Studies have shown that extracts of sage plant possess antiproliferative, cytotoxic and pro-apoptotic effects on different cancer cell lines such as lung carcinoma, melanoma, breast cancer, laryngeal carcinoma, oral cavity squamous cell carcinoma and colorectal cancer [5-7]. Ifosfamide (IFO), an oxazaphosphorine alkylating cytotoxic agent, is commonly used to treat solid tumors such as sarcomas, breast cancer, lymphoma and lung cancer, alone or in combination with other anticancer drugs [8]. The toxicity of IFO is attributed to its reactive metabolite, chloroacetaldehyde (CAA). Only a few studies have reported the hepatotoxic effect of IFO. Cases of liver failure after treatment with a combination of IFO and docetaxel for advanced breast cancer treatment or sarcoma have been reported $[9,10]$. In a previous study, hepatotoxicity combined with Fanconi syndrome was reported in female rats [11]. The aim of this study was to investigate the hepatotoxic and hematotoxic effects of sage oil- loaded IFO NE in EAC-bearing mice.

\section{EXPERIMENTAL}

\section{Chemicals}

Ifosfamide (IFO) was purchased from Baxter (USA); Span 20 and Tween 80 were obtained from Sigma (USA), while sage oil was purchased from Sokar Nabat for Natural Oils (Saudi Arabia). Phosphate buffered saline (PBS) was a product of Bio-Diagnostics Company (Egypt). Automated cell counter was obtained from Beckman (USA). Inverted light microscope was a product of Olympus Optical Co., Ltd. (Japan).

\section{Preparation of sage oil-based NE}

Sage oil-based NE was prepared by adding, in drops, $5.5 \%$ (v/v) surfactant mixture (Tween 80 and Span 20, 2:1, v:v); $1.8 \%$ sage oil, and 92.7 $\%$ water until a clear and transparent solution was obtained after thorough mixing and heating at $70^{\circ} \mathrm{C}$.

\section{Experimental rats}

Female Swiss albino mice $(\mathrm{n}=50)$ weighing 25 $30 \mathrm{~g}$ (mean weight $=27.5 \pm 2.50 \mathrm{~g}$ ) were obtained from King Fahd Center for Medical Research, King Abdulaziz University (Saudi
Arabia), and were randomly assigned to five groups of 10 rats each. They were maintained under standard laboratory condition: $25^{\circ} \mathrm{C}, 12 \mathrm{~h}$ light/dark cycle and 60 - $65 \%$ humidity. The rats were allowed free access to standard rat feed and clean water. The study protocol was approved by the Institutional Research Ethics Committee of the Faculty of Medicine, King Abdulaziz University (Approval no. 1-17-01-0090068). The guidelines for the proper use and care of animals, prepared by the National Academy of Sciences, National Institute of Health, were followed to provide humane care to all the mice [12].

\section{Experimental design}

With the exception of group 1, the mice were inoculated intraperitoneally (i.p.) with $2.5 \times 10^{6}$ $\mathrm{EAC} / \mathrm{mouse}$ for $48 \mathrm{~h}$. Group I served as negative control, C (-); group II served as positive control, $\mathrm{C}(+)$, while groups III - V were i.p. treated with $60 \mathrm{mg} / \mathrm{kg}$ bwt IFO in $0.3 \mathrm{~mL}$ water (free-IFO), 0.3 $\mathrm{mL}$ NE (SAGE-NANO), and $60 \mathrm{mg} / \mathrm{kg}$ bwt IFO in $0.3 \mathrm{~mL}$ SAGE-NANO (SAGE-IFO), respectively. The treatments lasted three days [13].

\section{Blood and tissue sample collection}

On the fifth day of treatment, the mice were fasted overnight and sacrificed via cervical dislocation. They were anesthetized with diethylether. Blood sample was collected from the venous sinus in EDTA or plain tubes for biochemical analysis. The blood was centrifuged at $3000 \mathrm{rpm}$ for $15 \mathrm{~min}$ to obtain plasma or serum sample which was refrigerated at $-80{ }^{\circ} \mathrm{C}$ prior to use. Mice liver and spleen were excised, washed with PBS and subjected to histopathological examination. Portion of the liver was used to prepare $20 \%$ tissue homogenate which was used for determination of oxidative status of the mice.

\section{Determination of relative liver weight}

Following sacrifice, the liver was excised, blotted dry and directly weighted after sacrifice to calculate the organ weight ratio for each mouse by dividing the weight of liver with pre-sacrifice body weight of the same mouse.

\section{Assessment of liver function}

Serum activities of AST, ALT and alkaline phosphatase (ALP), and concentrations of total protein (TP), albumin, total bilirubin (T.Bil) and direct bilirubin (D.Bil) were determined using their respective kits. 


\section{Determination concentrations of antioxidant enzymes and molecules}

Catalase activity was determined using the method described by Aebi [14]. The concentration of MDA was measured based on a previously reported method [15]. Concentration of GSH was estimated according to the method of Beutler et al [16], while GR activity was determined using the method described by Goldberg et al [17].

\section{Hematological investigation}

Complete blood count (CBC) was carried out using automated cell counter.

\section{Histopathological examination}

Sections of excised liver and spleen were prepared for histopathological examinations. The tissues were cut into slices $(5 \mu \mathrm{m})$ using a microtome, fixed in $10 \%$ formaldehyde, dehydrated through gradient of alcohol, embedded in paraffin blocks, and sectioned. They were thereafter stained with hematoxylin and eosin (H \& E), and viewed under an inverted light microscope.

\section{Statistical analysis}

Data are expressed as mean \pm SEM. Statistical analysis was performed using MegaStat Excel (10.3). Groups were compared using Tukey's range tests. Values of $p<0.05$ were considered statistically significant.

\section{RESULTS}

\section{Liver function}

There were no significant differences in relative weights of liver and concentrations of TP among the groups $(p>0.05)$. The activity of AST was significantly elevated in all the EAC-bearing mice, when compared with $\mathrm{C}(-)$ group $(p<0.05)$. However, the activities of AST in SAGE-NANO and SAGE-IFO groups were significantly reduced, relative to free-IFO group $(p<0.05)$. The activity of ALT was significantly elevated in $\mathrm{C}(+)$ and free-IFO groups, when compared with C (-) group $(p<0.05)$. However, there were no significant differences in ALT activities in SAGENANO and SAGE-IFO groups relative to $C(-)$ group $(p>0.05)$. There were no significant differences in ALP activities among the groups, except the SAGE-NANO group $(p>0.05)$.

In the SAGE-NANO group, ALP activity was significantly elevated, when compared with the other groups $(p<0.05)$. Albumin level was significantly higher in EAC-treated groups than in $\mathrm{C}(-)$ and $\mathrm{C}(+)$ groups $(p<0.05)$. The concentrations of albumin in free-IFO and SAGEIFO groups were significantly higher than that in SAGE-NANO $(p<0.05)$ group. The level T.Bil was significantly increased in $C(+)$ group, relative to the other groups $(p<0.05)$. However, D.Bil level was significantly reduced in $C(-)$ and C (+) groups, when compared with the other groups $(p<0.05)$. These results are shown in Table 1.

\section{Oxidative status of mice}

Catalase activity was significantly reduced in $\mathrm{C}$ $(+)$ and free-IFO groups, when compared with SAGE-IFO, SAGE-NANO and C (-) groups ( $p<$ 0.05). Injection of free-IFO into the mice significantly elevated the concentration of MDA and significantly reduced the activities of the antioxidant enzymes ( $p<0.05)$. However, SAGE-IFO treatment significantly ameliorated the oxidative stress induced by free-IFO ( $p<$ $0.05)$.

The activities of catalase were significantly reduced in $\mathrm{C}(+)$ and free-IFO groups relative to C (-), SAGE-IFO and SAGE-NANO groups, while MDA level was significantly increased in $C(+)$ and free-IFO groups, when compared with $\mathrm{C}(-)$,

Table 1: Relative liver weight and liver function indices

\begin{tabular}{lccccc}
\hline Parameter & C (-) & C (+) & free-IFO & SAGE-NANO & SAGE-IFO \\
\hline Liver weight $\left(\times 10^{-2}\right)$ & $4.70 \pm 0.90$ & $5.50 \pm 0.60$ & $5.70 \pm 0.80$ & $5.80 \pm 0.99$ & $5.50 \pm 0.30$ \\
AST $(\mathrm{U} / \mathrm{mL})$ & $99.70 \pm 1.30$ & $117.90 \pm 3.80^{\mathrm{a}}$ & $132.90 \pm 3.50^{\mathrm{a}}$ & $126.15 \pm 0.20^{\mathrm{ab}}$ & $127.90 \pm 0.30^{\mathrm{ab}}$ \\
ALT $(\mathrm{U} / \mathrm{mL})$ & $75.30 \pm 1.10$ & $81.56 \pm 2.60$ & $83.60 \pm 0.80$ & $77.40 \pm 4.60$ & $74.70 \pm 1.54$ \\
ALP $(\mathrm{U} / \mathrm{L})$ & $142.10 \pm 1.05$ & $148.40 \pm 8.07$ & $138.40 \pm 1.50$ & $174.76 \pm 8.00^{\mathrm{c}}$ & $149.60 \pm 8.20$ \\
TP $(\mathrm{g} / \mathrm{dL})$ & $0.56 \pm 0.02$ & $0.55 \pm 0.03$ & $0.57 \pm 0.03$ & $0.57 \pm 0.04$ & $0.55 \pm 0.05$ \\
Albumin $(\mathrm{g} / \mathrm{dL})$ & $2.97 \pm 0.05$ & $3.04 \pm 0.01$ & $3.48 \pm 0.05^{\mathrm{a}}$ & $3.23 \pm 0.07$ & $3.77 \pm 0.02^{\mathrm{d}}$ \\
T.Bil $(\mathrm{mg} / \mathrm{dL})$ & $0.13 \pm 0.01$ & $0.15 \pm 0.00$ & $0.12 \pm 0.01^{\mathrm{e}}$ & $0.12 \pm 0.01^{\mathrm{e}}$ & $0.12 \pm 0.01^{\mathrm{e}}$ \\
D.Bil $(\mathrm{mg} / \mathrm{dL})$ & $0.01 \pm 0.00$ & $0.02 \pm 0.01$ & $0.05 \pm 0.00^{\mathrm{e}}$ & $0.04 \pm 0.01^{\mathrm{e}}$ & $0.06 \pm 0.01^{\mathrm{e}}$ \\
\hline
\end{tabular}

${ }^{a} P<0.05$, when compared with $\mathrm{C}(-)$ group; ${ }^{0} p<0.05$, when compared with free-IFO; ${ }^{c} p<0.05$, when compared with the other groups; ${ }^{d} p<0.05$, when compared with SAGE-NANO group; and ${ }^{\mathrm{e}} p<0.05$, when compared with $\mathrm{C}$ (+) group 


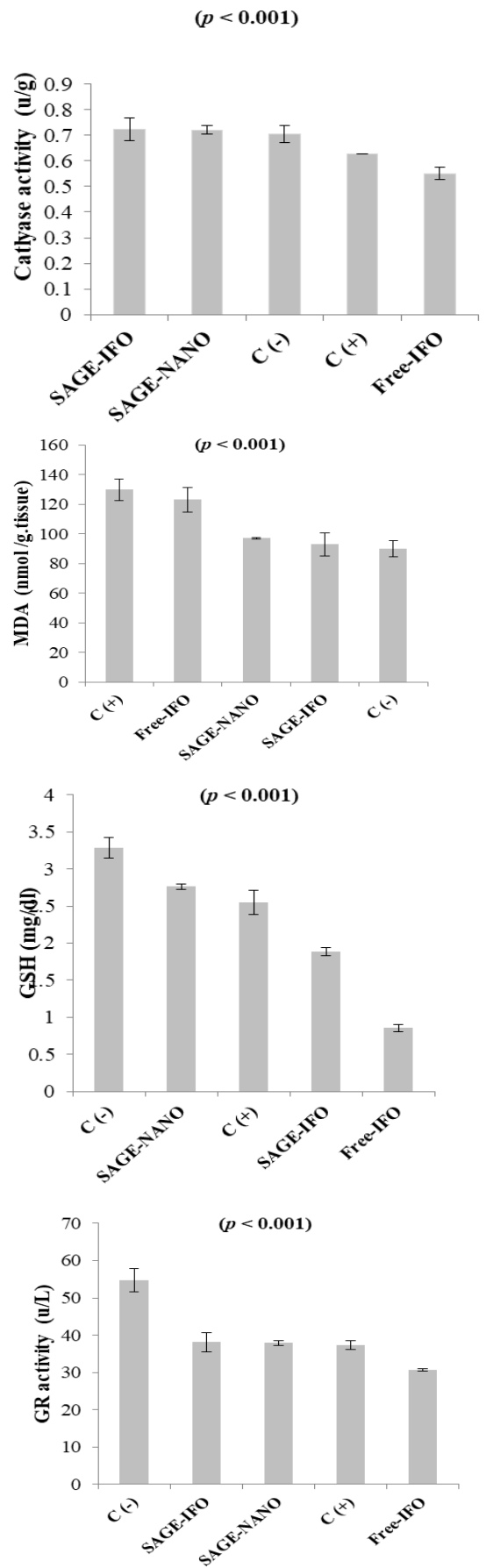

Figure 1: Some biochemical activities of mice

SAGE-IFO and SAGE-NANO groups $(p<0.05)$. The activity of GR was significantly higher in C (+) group than in the other groups, and it was significantly reduced in free-IFO group, relative to SAGE-IFO, SAGE-NANO and C $(+)$ groups $(p<$ 0.05 ). The level of GSH was significantly higher in C (-) group than SAGE-NANO, C (+), SAGEIFO and free-IFO groups $(p<0.05)$. The order of GSH concentrations was: $\mathrm{C}(-)>$ SAGE-NANO > $\mathrm{C}(+)>$ SAGE-IFO > free-IFO. These results are shown in Figure 1.

\section{Hematological parameters}

As shown in Table 2, WBC level was significantly higher in $\mathrm{C}(+)$ and SAGE-NANO groups, when compared with the $C(-)$, free-IFO and SAGE-IFO groups $(p<0.05)$. Platelets were also significantly higher in $\mathrm{C}(+)$, free-IFO and SAGENANO groups than in $C(-)$ and SAGE-IFO groups $(p<0.05)$. There were no significant differences in the levels of RBC and $\mathrm{Hb}$ among the groups $(p>0.05)$.

\section{Histopathological features of mouse liver}

The results of histology are shown in Figure 2. Photomicrographs of hepatic tissue sections of $C$ (-) group showed of central vein (CV) surrounded by hepatocytes separated by vascular sinusoids. Liver section of $\mathrm{C}(+)$ group revealed several microscopic changes such as presence of prominent Kupffer cells and leukocyte infiltration around CV, and excessive dilated blood sinusoids, when compared with C (-) group. Vasodilatation, presence of abundant Kupffer cells and leukocyte infiltration, in addition to some enlarged hepatocytes were observed in the liver section of free-IFO group. The leukocyte infiltration around CV was significantly reduced, and non-dilated blood sinusoids were seen in the hepatic tissue of SAGE-NANO group relative to C (+) group. Liver section of SAGE-IFO group revealed less dilated blood sinusoids and leukocyte infiltration than those of $\mathrm{C}(+)$ and freeIFO groups.

\section{Histopathological characteristics of mouse spleen}

Normal spleen architecture was observed in C (-) group as evidenced by the presence of red pulp and lymphoid white pulp, which consisted of

Table 2: Levels of hematological parameters in the different groups

\begin{tabular}{lccccc}
\hline Parameter & $\mathbf{C}(-)$ & $\mathbf{C}(+)$ & free-IFO & SAGE-NANO & SAGE-IFO \\
WBC $\left(1 \times 10^{3} / \mu \mathrm{L}\right)$ & $1.70 \pm 0.02$ & $2.35 \pm 0.05$ & $1.20 \pm 0.01^{\mathrm{a}}$ & $2.50 \pm 0.01^{\mathrm{a}}$ & $1.77 \pm 0.10^{\mathrm{a}}$ \\
Platelets $\left(1 \times 10^{3} / \mu \mathrm{L}\right) \times$ & $7.15 \pm 0.43$ & $8.58 \pm 0.30$ & $8.36 \pm 0.55^{\mathrm{b}}$ & $10.54 \pm 0.28^{\mathrm{b}}$ & $6.87 \pm 0.70$ \\
$10^{2}$ & $8.91 \pm 0.12$ & $8.94 \pm 0.19$ & $8.71 \pm 0.49$ & $8.27 \pm 0.05$ & $8.62 \pm 0.28$ \\
$\mathrm{RBC}\left(1 \times 10^{6} / \mu \mathrm{L}\right)$ & $13.80 \pm 0.80$ & $14.50 \pm 0.35$ & $13.70 \pm 0.30$ & $13.85 \pm 0.25$ & $13.85 \pm 0.50$ \\
$\mathrm{Hb}(\mathbf{g} / \mathrm{dL})$ & ${ }^{\mathrm{a}} P<0.05$, when compared with $\mathrm{C}(+)$ group ${ }^{\mathrm{b}} \mathrm{P}<0.05$, when compared with $\mathrm{C}(-)$ group
\end{tabular}


periarteriolar lymphoid sheaths (PALS), adjacent follicles and marginal zone. However, significant reduction of lymphocytes with no clear border between red pulp and white pulp was evident in $\mathrm{C}(+)$ group, while the spleen section of SAGENANO group revealed decreased lymphocytes with clear borders. Spleen sections of free-IFO and SAGE-IFO groups revealed the presence of lymphocytes (Figure 3).

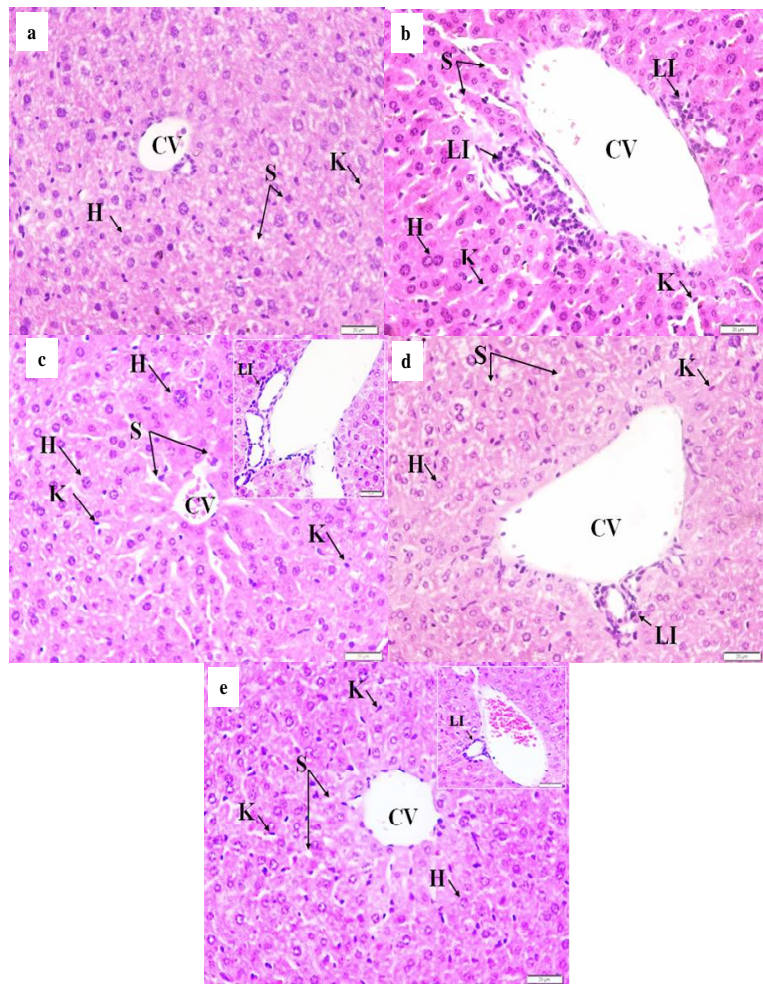

Figure 2: Tissue sections of liver stained with $\mathrm{H}$ \& $\mathrm{E}$ ( $\mathrm{x}$ 400). (a): C (-) tissue showing normal liver histology including CV, blood sinusoids $(\mathrm{S})$, hepatic cells $(\mathrm{H})$ and Kupffer cells (K); (b): C (+) tissue showing enlarged CV, excessive dilated blood sinusoids, hepatocytes with prominent Kupffer cells, infiltration of tumor cells, and leukocytes (LI); (c): Free-IFO tissue showing excessive dilated blood sinusoids, leukocyte infiltration and enlarged hepatocytes with abundant Kupffer cells; (d): SAGE-NANO tissue showing minute leukocyte infiltration around $\mathrm{CV}$, blood sinusoids close to normal structure; and (e): SAGE-IFO tissue showing dilated blood sinusoids and leukocyte infiltration less than that of $\mathrm{C}(+)$ and free-IFO tissues, hepatocytes with prominent Kupffer cells

\section{DISCUSSION}

Nanoemulsions (NEs) are single-phase and thermodynamically stable isotropic systems that consist of emulsified oil, water and amphiphilic molecules. They are sub-micrometre-sized emulsions that are under extensive investigation as drug carriers for improving the delivery of therapeutic agents [1]. The present study investigated the hepatotoxic and hematotoxic effects of sage oil-loaded IFO NE in EAC-bearing mice.

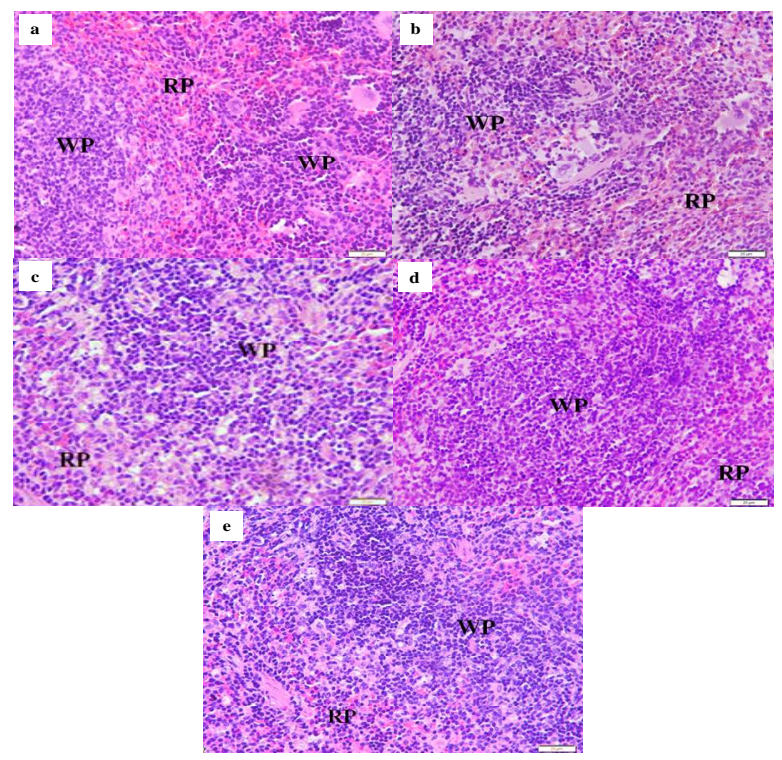

Figure 3: Histological sections of spleen stained with $H$ \& $E$ (x 400). (a): C (-) tissue showing normal morphology of spleen characterized by red pulp (RP) and lymphoid white pulp (WP); (b): C (+) tissue revealing severe reduction of lymphocytes in the periarteriolar lymphoid sheaths (PALS) of the WP with undefined boundary between WP and RP; (c): FreeIFO tissue displaying WP with basically normal numbers and arrangement of lymphocytes in the PALS and follicles; (d): The WP in SAGE-NANO tissue showing reduction of lymphocytes in PALS; and (e): SAGE-IFO tissue presenting WP with basically normal numbers and arrangement of lymphocytes in the PALS and follicles

Elevation of serum activities of AST, ALT and ALP are indicative of acute liver toxicity $[10,11]$. In this study, AST and ALT activities in free-IFO group were significantly increased, while administration of the combined formula, SAGEIFO, significantly reduced the activity of these liver enzymes. On the other hand, activities of ALP in free-IFO and SAGE-IFO groups were not significantly different from that of $C(-)$ group. The concentration of direct bilirubin was significantly increased in free-IFO and SAGE-IFO groups, suggestive of hepatotoxicity induced by IFO [18].

There was induction of oxidative stress in freeIFO group, indicative of impairment of the antioxidant defence mechanism in the mice. The activities of GR and catalase, and concentration of GSH were significantly reduced, and concentration of MDA was significantly increased in free-IFO mice. The activity of GR, and GSH level were significantly increased, and the activity of catalase and concentration of MDA were 
normalised in SAGE-IFO group, when compared with free-IFO group. The results of histopathological examination revealed the presence of inflammatory leukocyte infiltration in the liver of free-IFO group. Degeneration of the liver may have resulted from IFO toxic metabolite, CAA, which might have promoted GSH depletion and lipid peroxidation in the hepatocyte [19].

The inclusion of sage oil in SAGE-IFO formula may have contributed in diminishing IFO toxicity. A number of studies have reported the antiproliferative, anti-migratory, anti-angiogenic and antioxidant activities of sage oil $[7,20]$. Sage oil plays increases the activity of glutathione peroxidase, which in turn protects hepatocytes from dimethoxy naphthoquinone and $\mathrm{H}_{2} \mathrm{O}_{2}$ induced DNA damage. It has been reported that oxidative stress in rat hepatocytes may be improved by drinking water enriched with sage extract [21]. Studies have also shown that the sage extract, rosmarinic acid stimulates the activities of various antioxidant enzymes such as pancreatic catalase, glutathione peroxidase, glutathione-S-transferase and superoxide dismutase in streptozotocin-induced diabetic rats [22].

Hematological parameters are markedly affected by the growth of tumor cells. Tumor cells induce the release of vascular endothelial growth factor (VEGF), which is an angiogenic factor stored in platelet granules [22]. In this study, the levels of WBCs were significantly higher in $\mathrm{C}(+)$ and SAGE-NANO groups, when compared with C (-), free-IFO and SAGE-IFO groups. Platelet levels were significantly higher in $C(+)$, free-IFO and SAGE-NANO groups than in $C(-)$ and SAGEIFO groups. There were no significant differences in the levels of red blood cell (RBC) and hemoglobin among the groups. These results suggest that sage oil may possess antiangiogenic properties. It has been reported that ethanol extract of sage inhibits the proliferation and migration of human umbilical vein endothelial cells (HUVECs) and prevents VEGF expression in breast cancer cells (MCF-7) [23]. It has also been reported that EAC raises the level of WBC, which reflects acute inflammatory response or stress due to metastasis of the cancer cells [24]. These results also suggest that sage oil when used to formulate NE may improve drug penetration which leads to reduced tumor inflammation [25].

\section{CONCLUSION}

The results obtained in this study suggest that loading IFO in sage oil-NE greatly reduces its hepatotoxicity and hematotoxicity.

\section{DECLARATIONS}

\section{Acknowledgement}

The authors wish to sincerely thank King Abdulaziz City for Science and Technology for financial support for this work (project no. 1-1701-009-0068).

\section{Conflict of interest}

No conflict of interest is associated with this work.

\section{Contribution of authors}

We declare that this work was done by the authors named in this article and all liabilities pertaining to claims relating to the content of this article will be borne by the authors.

\section{Open Access}

This is an Open Access article that uses a funding model which does not charge readers or their institutions for access and distributed under the terms of the Creative Commons Attribution License (http://creativecommons.org/licenses/by/ 4.0) and the Budapest Open Access Initiative (http://www.budapestopenaccessinitiative.org/rea d), which permit unrestricted use, distribution, and reproduction in any medium, provided the original work is properly credited.

\section{REFERENCES}

1. Jaiswal $M$, Dudhe $R$, Sharma $P$. Nanoemulsion: an advanced mode of drug delivery system. 3 Biotech 2015; 5 (2): 123-127.

2. Bilia AR, Guccione $C$, Isacchi B, Righeschi C, Firenzuoli F, Bergonzi MC. Essential oils loaded in nanosystems: a developing strategy for a successful therapeutic approach. J. Evid. Based Complementary Altern. Med. 2014; 2014: 651593.

3. Al-Otaibi WA, Alkhatib MH, Wali AN. Cytotoxicity and apoptosis enhancement in breast and cervical cancer cells upon coadministration of mitomycin $C$ and essential oils in nanoemulsion formulations. Biomed. Pharmacother. 2018; 106: 946 - 955.

4. Alkhatib MH, Al-Otaibi WA, Wali AN. Antineoplastic activity of mitomycin $C$ formulated in nanoemulsions- 
based essential oils on HeLa cervical cancer cells. Chem. Biol. Interact. 2018; 291: 72 - 80.

5. Garcia CS, Menti C, Lambert AP, Barcellos T, Moura S, Calloni C, Branco CS, Salvador M, Roesch-Ely M, Henriques JA. Pharmacological perspectives from Brazilian Salvia officinalis (Lamiaceae): antioxidant, and antitumor in mammalian cells. An. Acad. Bras. Ciênc. 2016; 88 (1): 281 - 292.

6. Russo A, Formisano $C$, Rigano $D$, Senatore $F$, Delfine $S$, Cardile V, Rosselli S, Bruno M. Chemical composition and anticancer activity of essential oils of Mediterranean sage (Salvia officinalis L.) grown in different environmental conditions. Food Chem. Toxicol. 2013; 55: 42 - 47.

7. Kontogianni VG, Tomic G, Nikolic I, Nerantzaki AA, Sayyad N, Stosic-Grujicic S, Stojanovic I, Gerothanassis IP, Tzakos AG. Phytochemical profile of Rosmarinus officinalis and Salvia officinalis extracts and correlation to their antioxidant and anti-proliferative activity. Food Chem. 2013; 136 (1): 120 - 129.

8. Kerbusch $T$, de Kraker J, Keizer HJ, van Putten JW, Groen $H J$, Jansen RL, Schellens $J H$, Beijnen $J H$. Clinical pharmacokinetics and pharmacodynamics of ifosfamide and its metabolites. Clin. Pharmacokinet. 2001; 40 (1): 41 - 62.

9. Kosmas C, Tsavaris $N$, Malamos $N$, Stavroyianni $N$, Gregoriou A, Rokana S, Polyzos A. Phase I-ll study of docetaxel and ifosfamide combination in patients with anthracycline pretreated advanced breast cancer. Br. J. Cancer 2003; 88 (8): 1168 - 1174.

10. Cheung MC, Jones RL, Judson I. Acute liver toxicity with ifosfamide in the treatment of sarcoma: a case report. $J$. Med. Case Rep 2011; 5 (1): 180.

11. Aziz FM. Effect of Storing Temperature on Hepatotoxicity and Nephrotoxicity of Ifosfamide in Female Rat. Online J. Biol. Sci. 2012; 12 (1): 21 - 26.

12. Council NR. Guide for the care and use of laboratory animals: National Academies Press; 2010.

13. Hanly L, Figueredo R, Rieder M, Koropatnick J, Koren G. The effects of $\mathrm{N}$-acetylcysteine on ifosfamide efficacy in a mouse xenograft model. Anticancer Res. 2012; 32 (9): 3791 - 3798.

14. Aebi H. Catalase in vitro. Methods in enzymol. 1984; 105 : 121-126.
15. Kei S. Serum lipid peroxide in cerebrovascular disorders determined by a new colorimetric method. Clinica chimica acta 1978; 90 (1): 37 - 43.

16. Beutler E, Duron O, Kelly BM. Improved method for the determination of blood glutathione. J. Lab. Clin. Med .1963; 61: 882 - 888.

17. Goldberg $D$, Spooner $R$. Methods of enzymatic analysis. Bergmeyer HV. 1983; 3: 258 - 265.

18. Paschke R, Worst P, Brust J, Queisser W. Hepatotoxicity with etoposide-ifosfamide combination therapy. Onkologie. 1988; 11 (6): 273 - 275.

19. Weber GF, Waxman DJ. Activation of the anti-cancer drug ifosphamide by rat liver microsomal $P 450$ enzymes. Biochem Pharmacol. 1993; 45 (8): 1685 1694.

20. Kozics $K$, Klusová V, Srančíková A, Mučaji $P$, Slameňová $D$, Hunáková L', Kusznierewicz B, Horváthová E. Effects of Salvia officinalis and Thymus vulgaris on oxidantinduced DNA damage and antioxidant status in HepG2 cells. Food chem. 2013; 141 (3): 2198 - 2206.

21. Horváthová $E$, Srančíková $A$, Regendová-Sedláčková $E$, Melušová $M$, Meluš V, Netriová J, Krajčovičová Z, Slameňová $D$, Pastorek $M$, Kozics $K$. Enriching the drinking water of rats with extracts of Salvia officinalis and Thymus vulgaris increases their resistance to oxidative stress. Mutagenesis. 2015; 31 (1): 51 - 59.

22. Thummar VR, Parasuraman $S$, Basu $D$, Raveendran $R$. Evaluation of in vivo antitumor activity of cleistanthin $B$ in Swiss albino mice. J. Tradit. Complement Med. 2016; 6 (4): $383-388$.

23. Zihlif M, Afifi F, Abu-Dahab R, Majid AMS A, Somrain $H$, Saleh MM, Nassar ZD, Naffa R. The antiangiogenic activities of ethanolic crude extracts of four Salvia species. BMC Complement Altern. Med. 2013; 13 (1): 358.

24. Rahman MS, Alam MB, Choi YH, Yoo JC. Anticancer activity and antioxidant potential of Aponogeton undulatus against Ehrlich ascites carcinoma cells in Swiss albino mice. Oncol Lett. 2017; 14 (3): 3169 3176.

25. Ghorbani A, Esmaeilizadeh M. Pharmacological properties of Salvia officinalis and its components. J. Tradit. Complement Med. 2017; 7 (4): 433-440. 